\title{
8 Laboratories for economic expertise
}

\author{
Lay perspectives on Italian \\ disciplinary economics
}

Gerardo Costabile Nicoletta

\section{Introduction}

Economic expertise appears to be one of the most important organizational assets in global governance. This idea spreads from wider social public discussions to the deepest world of academia. While normative and prescriptive theoretical productions of global governance have reified forms and content of expertise and hypothesized subjects in a set of descriptive and procedural rules (Cayarannis et al., 2001), social studies of economics are currently offering several fundamental analytical starting points to understand the power and influence of economics in global political economy (see Maesse's contribution in this volume). This new scientific effort aims to overcome critical political economy representations of economic expertise as the mere linguistic appearance of dominant material class interests and hegemonic concepts (Van Apeldoorn, 2002; Bieler \& Morton, 2001). At the same time, newer insights in social studies of economics critically reframe visions of politics of expertise which implicitly assume economic expertise as a self-referential and autopoietic product of professional experts (Radaelli, 1999).

This chapter draws upon various strands of critical studies to offer a contribution to social studies of economics beyond the subjectivist-objectivist divide. The analysis proposes a transnational historical sociology of economics in the Italian national-linguistic context centred on a conceptualization of economic expertise as a power device. The chapter aims to highlight the contingent, contextual and relational dimensions of forms of power of economics, questioning the expert-lay relation in economics. I refer to laypeople as all those molecular and heterogeneous agencies which contingently and contextually resist, refuse, sabotage and threaten dominant socio-technical divisions of labour and relation of propriety. Accordingly, economist discursive practices are interpreted as producers of specialized epistemic fields able to establish the apparent neutrality of technologies of government. The argument is sustained by a theoretically informed narrative of three particular historical experiences from contemporary Italy understood as laboratories for economic expertise. The socio-historical narrative documents how transnational networks of economics, institutions, discourses and practices created discursive mechanisms able to 
separate socio-political subjectivities from material and organizational issues to get them in line within the socio-technical divisions of labour and relations of propriety.

The chapter is organized as follows. Section 2 introduces the ideas of laboratories of economic knowledge, jurisdictions and programmes to underline the strengths and limits of social studies on the analysis of the power of economics. It is argued that, amongst multiple dimensions of expertise, the power of economics should be analyzed from the discursive construction of the object of its intervention, i.e. laypeople. Section 3 further elaborates these conceptual tools in a theoretical discussion focusing on the relationship between economic experts and laypeople. The perspective that is presented informs the historical narrative of section 4, which is separated into three sub-sections. Section 4.1 reconstructs how economist interventions in Italy have produced spaces of affirmation for accumulation processes, experimenting with monetarism and developmental programmes. In this laboratory, it is argued, economic discursive practices aimed to separate socio-technical issues from social management and to get populations and territories in line with the Atlantic division of labour. Section 4.2 shows how economists have innovated technologies of thought to deal with the unmanageable reactions of socio-political subjectivities. The section highlights how transnational dialogues, systems of inscription, discourses and policy practices link together to rearticulate political society and state-cadre claims over national regulatory space. Finally, section 4.3 illustrates how economists have promoted the European Union (EU) as a new institutional socio-spatial configuration to foster industrial restructuring and financial innovations able to sterilize workplace tensions and to separate at the highest level of decision-making in economic policy. The section will show how economic expertise aimed to transform the Italian context aligning population and territories according to transnational preferences. Such attempts clashed with silent resistances and explosive insubordinations of its object of intervention: laypeople.

\section{The power of economics and the laboratory for economic expertise}

The idea of a laboratory associated with economic discipline is not new. The most common example of laboratory for economic expertise is the 'Chicago Boys', a group of neo-monetarist post-doc students, who experimented with neoliberal economic reforms in authoritarian Chile (Foxley, 1983; Klein, 2007; Dezalay \& Garth, 2011). The case of the Chicago Boys can easily be taken as a clear example of how ideas from global economic knowledge and policy practices intervene to shape national and local contexts. This idea of a national system used as a laboratory for specific policy programmes refers to the more general question about how global, domestic and local dimensions interact through globally produced knowledge working in specific socio-spatial contexts. Liberal constructivist approaches of epistemic community and advocacy 
coalitions have assumed that institutional learning and knowledge transfer by experts occurs due to growing complexity of global governance tools and mechanisms (Haas, 1992; Cayarannis et al., 2001). Indeed, if it is true that professional formations linked by and for global governance exist, we cannot simply assume the socio-political foundation of institutional forms within which groups of economic experts emerged in a position of power.

Moving beyond the opaque and ambiguous category of experts, inhabiting global governance, Fourcade (2006) suggests studying economists as part of transnational networks that are constantly redefining their (national) professional jurisdictions in order to empower their positions, in both global and domestic social stratification. Fourcade reminds us how, through the universalism of economic thought, its formal-modelling and abstract method, economics as a professional jurisdiction is easily applicable everywhere as a technology of bureaucratic power, shaping states and societies. The creation of economic jurisdiction is made "through its participation in the ongoing economic reconstruction of societies" (Fourcade, 2006:183), in a way that has allowed economists to creatively construct nation-state apparatuses in which the profession of economics has found its privileged place of professional and social institutionalization. The international and national diffusion of capital investments is the Trojan horse through which professional economists influence societies both materially and discursively. Therefore, each corner of the globe can be seen as the potential playground in which professional economists apply abstract knowledge to control the general conditions of labour activity. This construction and reconstruction of domains of intervention by economists as agents of globalization seem to have an auto-generative principle since it is "largely an endogenous process, rather than a result of external forces" (Fourcade, 2006:183; emphasis added). In this vision, economists follow the capital expansion and support it through the production of knowledge, while local agents, state technical elites and political society at large are somehow forced to get more and more 'economical'. Even though the subjective creativity of professional economists would be able to set up laboratories to shape society at large, we have to consider that there exist creative and resistive practices adopted by agencies on the playground of economic governance. These creative resistances, I will argue, force economists to continually redefine their interventions.

Overcoming this subjectivist starting point, Dezalay and Garth (2011) have placed economist agencies within a macrostructural sociology enriched by a Bourdieusian reflexive and middle-range theory of the field. In their analysis, the internationalization of state apparatuses represents a field of power in which core countries' professionals experiment with governmental practices. More specifically, the international market of governing expertise, which is mainly constituted by complex professional hierarchies of economics and law experts, represents a field where different socio-political forces engage to survive within imperialistic geopolitical tensions. The internationalization of state apparatuses has set a series of specific competitive dynamics in place between national technical elites and new professional subjectivities, in a global confrontation for 
gaining more power on domestic and international levels. In this intra-expert dynamic, peripheral countries are used as laboratories for core countries' juridical and economic experiments to impact future policy agendas. The exchange of theoretical knowledge, operative tools and institutional trust finds its experimental field in places where locals are caged in underdeveloped and subalternate positions. Eventually, the reflexive and structural sociology of expertise focuses on structural determinants shaping economists' power within the limits of their semantic and professional universe to improve their capacity to colonize state command hierarchies. The concept of the field, as the crystallization of power relations, appears unable to take into account the relational dimension that exists outside of pyramidal intra-elite conflicts. State technical elites and professionals belong to broader institutional and symbolic fields from which political society at large, subaltern groups and social formations are excluded.

Enlarging the analysis to what exists outside of different professional fields, Eyal and Bockman (2002) have stressed the role of local receivers of globally crafted programmes in the reproduction of economic discursive practices. Drawing upon Foucauldian framework and its sociological translation operated by Latour, they show how Eastern European real socialism was transformed in a laboratory for economic knowledge through which transnational networks were able to reorient economic debates and policies. According to this analysis, changes in economic policy take shape from constant transnational dialogues in which the role of translation is crucial, since it means "the ability of network builders to devise an interpretation that aligns their interests with the network's new recruits whose support and resources are crucial for its survival" (Eyal \& Bockman, 2002:314). The reproduction of economic discursive practices is thus managed by complex networks of agents, tools, texts, inscriptions and discourses, which are strategically mobilized to shape economic knowledge and debates in particular contexts. Indeed, economic experts are merely a component of these complex chains of significant inscriptions, contextually translating socio-political programmes and inventing new methods and devices for economic transactions (Eyal \& Bockman, 2002). For this reason, experts and expertise must be analyzed as two distinct dimensions, and the recognition of the role of audiences, receivers and laypeople, who are all involved in the formation of expertise (Eyal \& Buchholz, 2010), must also be considered. The next section proposes a theoretical discussion that focuses on the role of this broader field of analysis in the social formation and political intervention of economic expertise.

\section{The biopolitics of economic expertise}

Professional activities, intra-elites' conflicts over knowledge and symbols, organizational dynamics and audience construction are all shaping local and national contexts. This section discusses how this 'outside' dimension can be thought of and integrated into social studies of economics. If, sociologically speaking, there is not an expert without its counterpart, the layperson, the 
expert-lay relationship is anything but given. Instead, it is the result of a complex social-historical construction process in which mechanisms of inclusion and exclusion, acts of denomination and technologies of classification mesh with material conditions, technical language, gestures and practices giving shape to social and political projects. This processuality rests on particular social, political and epistemic orders in which representations and calculations are terrains through which forms of power operate. Considering these relational dynamics can show how globally produced abstract knowledge, institutions, state apparatuses and professional agencies link. For this reason, this section goes back to how economics emerged as a disciplinary field and how it structured its epistemic field. It will be argued that the discursive formations of economics create perceptive and linguistic patterns that shape experiences, practices, gestures and discourses of those who are outside its narrow semantic and professional field.

The disciplinary separation of the economic domain from the rest of social and political affairs emerged during the 19th century as an intellectual reaction against the First Workers International lay appropriation of the quasitranscendental category of labour-value produced by Scottish political economy (Foucault, 2013; Van der Pijl, 2011). Starting from a subjectivist reinterpretation of value by the marginalist revolution and its onto-epistemic corollary, economics was academically institutionalized at the beginning of the 20th century (Van der Pijl, 2011). To this disciplinary enterprise, Anglo-Saxon liberalism and its geopolitics offered the transnational network necessary to spread through Europe, where pure economics had to confront older philosophical traditions of thinking around material organizations and relations of propriety. Despite the fact that economics emerged because of state-phobia (Foucault, 2004), its epistemic field has played a fundamental role in the construction of national regulatory spaces, upon which the same idea of economy emerged. Due to the engagement of academic and professional organizations in national public institutions and international governance, this form of disciplinary economics has discursively reproduced the idea of economy as a given central category for framing any kind of political and institutional project: a force that political society can only affirm to be independent from social management (Mitchell, 2002:245). In confronting different particular normative interpretations of management, economics has developed its universal language, systems of explanation and modes of intervention in the public sphere. Mobilizing this apparatus, the economic expert (re)produces its discursive position in the socio-technical division of labour. This discursive position is grounded in specific representations of material and organizational life that deny validity to other forms of organizational projects. Separating the capitalist relation of propriety and socio-technical division of labour from social knowledge, economics' discursive practice produces its lay counterpart.

The expert-lay distinction operated by disciplinary economics is embedded in broader institutionalized discursive practices that establish social measurements, acts of denomination and classification, and exclusion as relations of power. Discourses and mundane practices make possible the economy as a 
socio-technical organization in which several devices of calculation are able to organize socio-technical settings (Mitchell, 2002:2). In this sense, the discursive practices of economics operate through sophisticated technologies of thought made by specific procedures of inscription, notation, data collection and counting (Miller \& Rose, 1990) and are sustained by the production of meta-historical narratives as organizing myths (Wallerstein, 2001:51). These meta-historical representations are meant to reinterpret retrospectively and normatively unknown processualism from the past with economic conceptual apparatuses. Both the synchronic and diachronic operativity of economics' epistemic field allow objects of discourse to be rendered in particular conceptual forms in order to be amenable to intervention and regulation. This interplay results in discursive mechanisms that define subjects and domains as intelligible and manageable, whereby positive knowledge and institutionalized practices create new technologies of governmentality to normalize actual or potential threats. People who are not participating in the linguistic formalization of this process and who are not (yet) consecrated to economics become, in this way, the object of economic discursive practices. In this sense, because of the separation of individuals, groups and organizations from the management of their autonomous (re)production, discursive practices of economists create their lay counterparts as subaltern so as to be in line with the dominant sociotechnical division of labour and relations of propriety.

From this point of view, the power of economics is not merely the formal linguistic reflection of material structures; neither can it be uniquely defined as a set of elite strategies or professional jurisdictions. The power of economics is rooted in the dissemination of knowledge devices that are operating locally, connecting transnational networks, epistemic apparatuses and technologies of bureaucratic power to deal with contingent and contextual situations. In Foucauldian terms, economic expertise is a device that creates and shapes knowledge, connecting heterogeneous elements to generate tactical and strategic goals (Foucault, 2013). It is not identifiable with a specific social formation, professional field, institution or ideology, but it denotes the contingent and strategic relation between groups, ideas and procedures. In this sense, transnational networks of economic experts are an immanent subjectivity of the device of economic expertise, mobilizing discourses, resources, media influences and academic production to deal with contingent and immediate situations. The biopolitics of economic expertise is a social microphysics constructed over a collective entity of populations and territories, separating and re-aligning individuals and organizations within socio-technical divisions of labour.

In the prescriptive definition of fundamental aspects of (re)productive life, the device of economic expertise has to repeatedly face different obstacles, resistances and hostilities. Economic governmentality is a "politically contested terrain" (Sanyal, 2008:255) where those who are governed confront, contest, sabotage and negotiate with the agents of governmentality and their neutrally presented political practices. In turn, such unpredictable and creative resistances by laypeople force economics to permanently restructure the forms and 
procedures of its intervention and sterilize potential and/or actual insubordinations against the socio-technical settings and relation of propriety. In this sense, reactions and insubordinations profane what economics separates in a sacred zone. In Agamben's (2009) theological interpretation of economy, profanation is a set of de-subjectivization practices of giving back to common use what the device of oikonomia (management) has separated into a sacred zone. Drawing from this suggestion, we consider our perspective to be a lay perspective that critically re-appropriates the subalternate position that economic discourses produce over people not consecrated to its socio-epistemic order, which questions and investigates what the disciplinary separation of social sciences sacralizes: the socio-technical division of labour and relations of propriety.

From this lay perspective, laboratories for economic expertise are not simply the product of symbolic exchanges within professional fields for the conquest of commanding state hierarchies, nor are they simply a form of legal jurisdiction through which abstract knowledge defines the general condition of people's forms of life. Rather, laboratories for economic expertise are transnational spaces of affirmation socio-historically crafted by and for economists and their discursive practices that aim at getting populations and territories in line with specific socio-political programmes. Since the 'living matter' of these laboratories is not so pliable and often profanes what economics sacralizes, transnational networks, institutions, system of inscriptions and modes of intervention all connect to innovate technologies of government. These strategic connections aim to separate from social management fundamental aspects of (re)productive life in specific socio-technical settings. Therefore, the lay perspective will highlight how economic expertise has separated from social and political subjectivities the design of their (re)productive life while inserting them in the needs of accumulation processes. Reactions and insubordination of subjectivities emerge from economic discursive formations and, in turn, innovate the economists' intervention.

\section{Lay perspective on Italian disciplinary economics}

Throughout the last thirty years, economists' discourses have held a privileged position in Italian structural reforms, in both the centre-left and centre-right government coalitions. The 2010 technical government lead by the ordoliberal economist Mario Monti, which surfaced in the midst of the debt sovereignty crisis in Europe, is just the latest example of economists' role in aligning national governmental agendas with transnational economic imperatives. This powerful position produced and was produced by representations of the economy as a zone that is neutral and separate from social claims, to be managed by technical measures that are guided by economic experts.

Through our lay perspective, this section proposes a transnational historical sociology of the forms of power of economics within the narrative of three experiences in contemporary Italy. The research is based on a qualitative bibliographical selection of both primary and secondary sources, which recompose 
key discursive events within the Italian national-linguistic field. Firstly, the narrative analyzes the economic experiment of monetarism and developmental policy. Economists' discursive interventions are interpreted as an attempt to separate the definition of economic order from social pressures to shape rural social settings in accordance with the new socio-technical division of labour crafted in the US hegemonic ascendancy. Then, it is shown how economists' discursive practices intervened to curb and rearticulate trade unions' claims, practices of insubordination and state-cadre pervasiveness. Finally, it is shown economists on the front lines of the construction of the EU as an institutional field to constitutionally separate monetary policy from socio-political pressure and to experiment with new socio-spatial sites of affirmation.

\subsection{The making of the Italian model of development (1922-1950)}

A degree of continuity with liberal governmental programmes characterized the first years of the fascist regime (Mattei, 2017). Initially, with its strong affirmation of the scientific division of labour in factories and its discipline enforced on the countryside, the fascist regime represented an armed form of liberalism, able to satisfy industrial and agrarian interests, with the compliance of the Atlantic powers (Gallo, 2009). However, in the aftermath of the 1929 crisis, liberal hegemony in the definition of the economic order began to be challenged. New economic public institutions intervening in the financial and industrial crisis, forged by state-cadres such as the Istituto per la Riscostruzione Industriale (Institute for Industrial Reconstruction) and Instituto Nazionale di Economia Agraria (National Institute of Agrarian Economics), entirely overcame traditional liberal practices for governing economic life while fascist corporative economics profaned pure economic dogmas. Within these ideological and organizational dynamics, a new generation of state economic technicians engaged in measuring activities and mapping the composition of the Italian population. Throughout the 1930s, statistical and demographic studies increased so much that in 1936 Istitutio Nazionale di Statistica (National Institute of Statistics) produced its first survey while national development became the core of a scientific enterprise within the institutional apparatuses (Patriarca, 2012).

The research department of the Italian central bank, the Servizio Studi, was at the centre of this institutional empowerment process. It represented, at the same time, the new-born brain of state financial monopolism and the leading domestic hub of international intellectual exchanges for young economists through fellowship programmes and experiences abroad (Scatamacchia, 2005). The link offered by the central bank research department gave institutional form to consolidated transatlantic networks and dialogues, enforced by the activity of private organizations such as the Rockefeller Foundation (Gemelli, 2005; Attal, 2012). In fact, against the coercive discipline of corporative economics imposed by the fascist regime, the intellectual resistance developed in transnational spaces of exchanges of ideas, theories, discourses and scientific 
practices. Due to these exchanges, Italian economics remained well connected to the Anglo-Saxon world thanks to the role of the Servizio Studi as the headquarters in the production of economic data, inscription, documents and analysis (Scatamacchia, 2005).

In 1943, when it was becoming clear that the fascist regime was collapsing, a group of Catholic economists intervened with a programmatic manifesto entitled the Codice Camaldoli. Reverberating ordoliberal principles of social market economy and constitutional order, this manifesto expressed the Catholics' biopolitical project founded on social hierarchies, professional authority, family and productivity. It was the product of the economization of Catholic public discourse, and it saw the integral intervention of state economic institutions as a virtuous experience for the construction of a proper Christian socio-economic order (Persico, 2014). According to Catholic economists working in emerging state institutions, public holdings and state apparatuses could act positively on the formation and accumulation of capital (Baietti \& Farese, 2010).

In the ideological framework outlined by Catholic economists, the state could question the relations of propriety when these appeared to be unwilling to create collective wealth (Magliulo, 1999). Moreover, in order to guarantee social justice and overcome class conflict, Catholic economists saw it necessary to transform proletarians into proprietors through state interventions in the agrarian relations of propriety. For different reasons, the Communist Party (PCI) at the time also shared the same productivist appeal, interpreting the factory system as the natural socio-technical organization (Righi, 2011), on which to construct a robust democratic state projected towards a socialist society. Both Catholics and Communists worried about the social unrest in the countryside. In fact, the end of fascism's ruralist discipline led to the outbreak of peasant jacqueries and revolts. Peasants' insubordinations questioned the socio-technical division of labour and relations of propriety. At the same time, they proposed alternative socio-political management of (re)productive life through common propriety of private estates (Ammendolia, 1990; Renda, 1980).

In 1946, during the discussion about the ratification of the expert statement of Bretton Woods that took place in the constituent assembly of the newborn Republic, the consensus over state interventionism of the anti-fascist alliance was immediately rearticulated. Translating Hayek's and Robbins's ideas on market federalism, the liberal economist and Rockefeller fellow Luigi Einaudi discursively insulated any possible alternative to the integration of state apparatuses into higher international political organisms, which was hoped would be better than the golden standard that the interwar years had destroyed (Masini, 2012; Cafaro, 2008). With the discourse of a binding engagement with the international community, the years of the constituent assembly became years of active austerity measures used as a therapy for guaranteeing monetary stability as the fundamental condition for economic development.

From 1945 to 1948, this discourse informed the so-called linea Einaudi. As the governor of the central bank and minister of budget, Einaudi applied the quantitative monetary theory and liberal governmental practices on the 
national economy, experimenting with the first set of monetarist policies of the postwar era. The tax increase, the abolition of political prices over food and the stop on bank credit to new industries intended to discipline any extraeconomic attempts at managing purchasing power. Meanwhile, the reports of the Treasury structured a new national economic balance, which was built on the accounting of resources of internal production, public expenditures, investments and family consumption. Since the linking of commercial balance to any possible economic-political programmes, innovations in accounting started to offer powerful cognitive infrastructure for the discourse on external constraints.

In 1947, US government interventions enforced the new state's binding engagement. The Marshall Plan suspended the activities of the Bretton Woods institutions and intervened to financially and scientifically sustain industrial and technological development, importing new procedures, inscriptions and reports. In order to contain any possible political threats to US geopolitical aspirations, American experts pushed for the integration of the country into divisions of labour oriented to and guided by the US. The austerity therapy of liberal economists created the need for extraordinary interventions to foster capital formation and socio-technical developments, even shortly after the end of the Marshall Plan aid. It is in this context that the territories of southern Italy become the privileged object of economist discursive practices. Already since 1946, the Association for the Industry in the South (SVIMEZ), founded by Catholic economists, translated the southern question from a socio-political issue into a technical and economic object, to be studied, treated and guided by economic experts. With the Servizio Studi, the SVIMEZ became the new gravitational centre for Anglo-Saxon economists who found Italy an interesting case study for economics (D’Antone, 1995). Overpopulation became the common object of intervention for Catholic economists and international economic experts. At the centre of its scientific production and in order to curb the excess of workforce and limited resources, the economist RosensteinRodan $(1943,1944)$ presented the project of integration of underdeveloped areas within the global division of labour. In 1948, as the head of International Bank for Reconstruction and Development, Rosenstein-Rodan invented the impact loan, a plan investment based on an organic programme of long-term development. Invited by the Servizio Studi, the economist Vera Lutz (1963) later formalized her vision on the export of manpower as the privileged solution for resolving territorial imbalance. The idea that emerged out of this was the total restructuring of agrarian settings to liberate manpower that could fulfil export-led industries' needs.

These discursive formations that emerged in transnational networks of economics were practically sedimented in the institution of the Cassa per le opere straordinarie per il Mezzogiorno (Fund for the south) founded in 1950. Based on a meta-historical representation of economic development, the Cassa's extraordinary intervention intended to foster the conditions for capital formation and accumulation in southern areas through the mobilization of unused manpower and the creation of a sound basis for industrialization. It aimed at intervening 
directly, through an expert-technical and independent guide, in the transformation of land settlements and in the mechanization of agricultural sectors as well as in the construction of communication infrastructures and tourist facilities. Connecting the Catholic biopolitical projects, US geopolitical aspiration and the liberal discourse, the economic expertise separated rural social formations from their own management of (re)productive life and got the population and territories in line with the production of the export-oriented industrialization of the new Atlantic division of labour.

\subsection{The crisis as governing expertise (1960-1977)}

At the beginning of the 1960s, the geopolitical conditions that guaranteed the functioning of industrial development disappeared. New productivity system calculations imposed by the General Agreement on Tarif and Trade and European Economic Community international agreements increased the rhythm of techno-organizational restructuring. Moreover, the restored convertibility and the Eurodollar markets offered investors strategies for escaping from state-cadre economic programmes. In this section, I illustrate how economic expertise linked new systems of inscription, new modes of intervention and financial innovations to curb and reframe rising claims over the definition of economic policy agenda, disciplining both trade unions and state-cadres.

The discursive mechanism crafted over the Italian southern territories and populations transformed socio-technical settings and, at the same time, increasingly enforced state-cadre public holding interventions. Throughout the 1950s, state-cadres had in fact expanded their influences over central sector industrial and service production, controlling $80 \%$ of the GDP through a capillary system of agencies for the management of public holdings performance and supplyside policies. In the 1960 s a new phase of the Cassa per il Mezzogiorno engaged in direct public industrial investments in the southern regions as well as in the functional control of the mobility of the southern population in order to feed northern industrial accumulation needs (Ferrari-Bravo \& Serafini, 1973). Crafted as subjectivity in the exodus from the countryside to the industrial triangle (Milan, Turin, Genoa), the populations started to radicalize. In 1962, a general strike of metalworkers, the manpower on which the export-led industry depended, enormously empowered the bargaining power of trade unions and obtained a substantial increase in wages. Since then, trade unions began to ask to sit at the table of economic programming opened by centre-left coalitions, aiming to change the direction of the model of development beyond low wages and low consumption (Lama, 1976).

This reformist appeal was immediately curbed by the management of the currency crisis, which was characterized by a new deflationary therapy. With the help of a new US loan, the central bank could face monetary instability through restrictions and avoid devaluation. This anti-inflationary policy imposed a violent restructuring of industrial sectors, provoking a crisis in full employment policies and political party machinery pervasiveness. With the 
return of deflationary therapy following the financial instability in 1963, the Servizio Studi engaged in knowledge production aimed at forecasting the economic behaviour of families, firms and public agencies. The interests of the economists of the Servizio Studi start to focus on the impact that central bank monetary policies had over people's expectations and activities. The renovation of the Servizio was promoted by the neo-governor Guido Carli, a highly reputable economist, who emerged out of corporativist economics and later affirmed himself in international economic institutions. Carli framed the central bank discourse around the idea of profit as the engine of development and credit as a fundamental element in investments. To guarantee the profits, it was necessary to link wage and productivity and enhance financial markets. In this discourse, the instrumental (i.e. political) use of the credit system by state-cadre elites and their political parties represented the main obstacle for an efficient economic system.

In 1962, financed by the Ford Foundation, the American economist Ackley (1962) published an econometric representation of the model of development for SVIMEZ. In the same years, an econometric model started to be experimented by the Servizio Studi, accompanied by short-term and long- to middle-term macroeconomic analyses. Its chief consultant was the US-based economist Franco Modigliani, who remained particularly active in public interventions on national media, as well as in the economic-academic production in specialized journals (Asso, 2010). Transposed by the Servizio Studi, the econometric model posed the balance of payment as the only independent variable in the economic system, namely a mathematical model which provided codified accounting practices to forecast the national economy as integrated into a highly competitive and unstable context. With the increasing social pressures and political conflicts over monetary management, the central bank economists adopted the econometric model to insulate calculations from the national government and political pressures (Peluffo, 2000).

Economists' innovations perform linguistic asymmetry in the knowledge of the economy in order to experiment with spaces of independence from sociopolitical pressures of the central bank. This system of inscription (re)produced by economic expertise caged trade unions and centre-left reformism in a lay position. New calculation technologies offered the discursive terrain where the wage increases of 1962 began to be depicted by economists as an internal shock. The innovation that emerged in the transnational symbolic exchange of economists did not stop the increasing pressure over financial management and industrial productivity. Public sectors continued to grow, especially in southern regions as indirect and politically mediated income redistribution. More importantly, the uprising of the political society of the 1970s forced the implementation of organic social legislations such as the Statuto dei lavoratori (1970). Workplaces became the terrain upon which radical fractions of trade union movement theorized the autonomy of the working class as the engine of technological development (Tronti, 2006). From 1969 the increasing tensions for the diffusion of extra-economic practices in workplaces and industrial cities 
became a serious problem for the economic governmentality. Sabotage and insubordination created an unmanageable incognito for economic programmes (Wright, 2002; Negri, 2012).

In 1974, the oil shock, capital outflows and increasing inflation led to a crisis of balance of payments. The central bank imposed a new austerity therapy to curb imports and consumption. In this context, experts of the International Monetary Fund experimented with massive loans conditioned to policy measures to stop the financial crisis. The econometric model of the Servizio Studi inspected the IMF 'letter of intention' and accepted the conditional loan. This emergency offered the terrain to rearticulate the increasing power of trade unions with the new context. Already in 1972, the economist Sylos Labini (1972) called for a new role of responsibility for trade unions in the context of growing global competition. In the same years, public interventions concerning the insertion of consumption in wage index, known as the 'Modigliani Controversy', opened a new discursive field which was successful in getting trade unions to accept low wages as a condition for rescuing productivity and avoid inflation (Masini, 2004). In 1976, Modigliani was invited by the PCI political and economic research centre to share his idea that inflation and balance of payments were the main interests of workers (Cattabrini, 2012). Simultaneously, the PCI then supported the cut of salaries and a new deflationary therapy. Hoping to obtain a seat in government, the PCI adhered to the austerity programme interpreted as anti-consumeristic policy. According to the general secretary of PCI, austerity could have been an occasion to transform the country (Berlinguer, 1977). In 1977, the EUR congress of Confederazione Generale Italiana del Lavoro (Italian General Confederation of Labour) marked up the end of wage growth as an independent variable. After being separated from claims over monetary policy, trade unions entered in the economic discursive field, accepting productivity and international competition as neutral domains.

\subsection{Economic experts as an EU constitutional force (1979-1993)}

The reactions, resistances and insubordinations by socio-political subjectivities forced economists to innovate technologies of government experimented with during industrial development. In this section, I conclude by narrating the active role taken by economists in accommodating industrial restructuring and financial innovations as technologies of government in order to sterilize conflicts in workplaces and in the management of public finance by political parties. Since the Piano Pandolf (1979), the European monetary coordination became the new terrain on which to construct knowledge hierarchies to discursively separate socio-political pressure from economic agenda.

In 1981, the economic expert of the different governments of the late 1970s, Beniamino Andreatta, together with the neo-governor of the central bank Ciampi, organized an open conspiracy to end the central bank's coverage of unsold state bonds. Conceived in the professional exchange between the 
Servizio Studi and the Massachusetts Institute of Technology (MIT), the London School of Economics (LSE) and Chicago University (Quaglia, 2005), the 'divorce' became the metaphor expressing the separation of decisional centres of state expenditure and the institute issuing money. With this decision, the Ministry of Treasury policies were judged by the markets (Andreatta, 1991), thus linking the financial resources of economic policy to investor preferences. The privatization of public debt was ratified without parliamentary discussion, and the undemocratic nature of this fundamental decision over state financing brought an end to the executive in 1982.

In 1983, the vice president of the European Commission, Étienne Davignon, pushed for the creation of an expert group that would be able to represent European industries and construct a permanent dialogue with them (Van Apeldoorn, 2002:85). The European Round Table of Industrialists was constituted as the organic intellectual group of European industry for the setting up of policy agendas and the relaunching of continental profitability. The discourses of euro-pessimism and euro-sclerosis pointed to a new social and political composition of valorization processes, which were forged on the absolute impossibility of returning to wage-driven policies. Labour-market rigidity became the leitmotif describing the source of stagflation. In the same year, a consultative scientific committee composed of economic experts was founded to study public debt management. The group of experts intended to guide the Ministry of Treasury towards the liberalization of financial sectors. For economic experts, 1992 represented a unique occasion to transform Europe as an economic and juridical space. According to the Italian economist Mario Monti, Europe offered a further step towards opening the door to the financial innovation that was needed to impose a competitive regime to credit institutes and force public administrations to engage in international competition (Castiglioni, 2013).

In its survey of Italy 1984-85, the Organisation for Economic Co-operation and Development (OECD) suggested that national government strongly implement reforms for overcoming political obstacles (Fouskas, 1998:83), such as the unwillingness of the political party machine to privatize public holdings and renounce their income (political) redistribution. In 1986, the macroeconomic policy group issued a report focusing on the role of capital in unemployment reduction. The report, presented by Modigliani, sustained that, in order to solve unemployment, a new wave of economic growth could be achieved through a series of fiscal and monetarily adequate policies (Castiglioni, 2013:35). Rescuing productivity and profitability became urgent for improving internationally linked financial services, for liberalizing financial sectors and for fostering industrial restructuring. Socialist neo-reformism resisted representing the national economy as a new economic growth locomotive supported by a modification of GDP calculation rules (Graziano, 2007:279) while workplace conflicts were sterilized by industrial restructuring.

In 1986, the European Single Act constrained monetary policy and liberalization directives and finally integrated them within the international financial 
system. With the institutional automatism launched by ESA, negative integration and deregulation were implemented in the midst of highly unstable political consensus. The construction of a scaffolding for European economic governance became the centre of economist discursive practices devising new economic methods able to confine economic reforms to technical and neutral domains. In 1992, during the intra-governmental arrangement of the Maastricht treaty, the juridical inquisition against extra-market practices of the governing class, known as Tangentopoli, offered the political vacuum for extra-parliamentary guidance by the Servizio Studi economists. In the definition of Mastricht parameters, the technocratic management of public finance through economist practices enforced economist positions and achieved what was not possible to achieve through parliamentary channels (Carli, 1993; Dyson \& Featherston 1996). The privatization of public holdings, the abolition of wage indexation and the liberalization of financial sectors began in 1993 with the technical government guided by the former governor of the central bank Ciampi.

The Italian neoliberal experiment has been forged by economists in order to discipline the political class and get workers' institutions in line with the restructuring era of the 80s. The dismissal and definitive end of the Cassa per il Mezzogiorno in 1992 reframed the socio-spatial configuration objectivating territories as collective economic actors facing off in international competition (Salento, 2014) and thus re-territorialized sites of affirmation for economic expertise to more local contexts. While decision-making is moved to a higher level of governance designated to lessening "short-run political pressures on the formulation of economic policy" (Gill, 1998), a new developmental framework, with its highly technical language, redefines territories through forms of bureaucratic power, economic discourses and policy practices, crafting subjectivities in line with the new European socio-technical division of labour.

\section{Conclusion}

This chapter has investigated forms of power of economics, focusing on contextual reactions and contingent resistances of the object of economic intervention: laypeople. From this lay perspective, economic expertise is not a neutral organizational asset. It does not represent an autopoietic force producing selfreferential knowledge in order to let particular fractions survive in social stratification; neither is it a mere battlefield for national and international professional vocation. Instead, economic expertise is the relationship between professionals, theories, data, operative epistemologies, institutions, public interventions, and social and geopolitical tensions. This concatenation of heterogeneous elements is produced within the tension between transnational networks and institutions facing contingent situations. As the historical narrative has shown, the connection of Catholic biopolitical project, US geopolitical aspirations and (neo)liberal programmes created new strategical fields of knowledge to reframe potential threats over postwar order. The discursive mechanisms produced by economic interventions objectivized southern territories and population, representing 
the economy as an independent and separated domain from social conflicts and political management. In doing so, economic expertise subjectivized southern peasantry as exportable manpower got in line within the Atlantic division of labour. Through knowledge devices operating locally, economic expertise shaped socio-political subjectivities consecrated to economic epistemic fields. In this way, lay subjectivities were caged in a subaltern position, misrecognizing the arbitrariness and the socio-political foundation of economics.

The economists' discursive position in defining way of life enjoyed power and authority as long as those subjectivities did not reclaim the power of definition of government agenda. As I have shown, during the 1970s unforeseen and unmanageable reactions of lay subjectivities overthrew the effectiveness of economic discursive practices. Due to these reactions, transnational networks of economists had to contextually innovate representations, calculations and interventions. The European neo-constitutional initiative represents an institutionalized site of affirmation for economic expertise to foster accumulation processes and innovate technologies of government. In this way, economic expertise has forged its lay population integrated within the permanent restructuring of socio-technical divisions of labour but immanently ready to explode to lay bare the arbitrariness of the epistemic field of economics.

\section{References}

Ackley G. (1962). An econometric model of Italian post war growth. SVIMEZ, Rome.

Agamben G. (2009). What is an apparatus? Stanford University Press, Stanford.

Ammendolia I. (1990). L'occupazione delle terre in Calabria 1946-1949 (Proletari senza Rivoluzione). Gangemi Editore, Rome.

Andreatta B. (1991). Il divorzio tra Tesoro e Bankitalia e la lite delle comari: uno scritto per il Sole24ore. Available at www.ilsole24ore. $\mathrm{com} / \mathrm{fccmd}=\operatorname{art} \& \operatorname{artId}=891110 \& \mathrm{chId}=30$.

Asso P. (2010). Franco Modigliani: L'impegno civile di un economista. Protagon editori, Toscani.

Attal F. (2012). The Rockefeller foundation fellows and grants in the humanities and social sciences, 1924-1970: Renewing social sciences, reshaping academic disciplines, and the making of a transnational network in Italy. Rockefeller Archive Center, New York.

Baietti S. \& Farese G. (2010). Sergio Paronetto and the Italian economy between industrial reconstruction of the 1930s and the reconstruction of the country in the 1940s. The Journal of European Economic History, vol. 39, no. 3, pp. 411-425.

Berlinguer E. (1977). Austerità occasione per trasformare l'Italia, Editori Riuniti, Rome.

Bieler A. \& Morton A.D. (2001). Social forces in the making of the new Europe: The restructuring of European social relations in the global political economy. Palgrave Macmillan, London.

Carli G. (1993). Cinquant'anni di vita italiana, collaboration with Paolo Peluffo. Economica Laterza, Bari.

Castiglioni C. (2013). Il tecnocrate. I trascorsi del prof. Mario Monti, economista e fiduciario dei poteri. Kaos edizioni, Milano.

Cayarannis E.G., Pirzadeh A. \& Popescu D. (2001). Institutional learning and knowledge transfer across epistemic communities. Routledge, London.

Cafaro P. (2008). La lira italiana e l'integrazione monetaria internazionale: il dibattito in sede di Costituente. In Il dilemma dell'integrazione. L'inserimento dell'economia Italiana nel sistema occidentale (1945-1957), edited by A. Cova. Franco Angeli, Milano. 


\section{Gerardo Costabile Nicoletta}

Cattabrini F. (2012). Franco Modigliani and the Italian left-wing: The debate over labor cost (1975-1978). History of Economic Thought and Policy, vol. 1, pp. 75-95.

D’Antone L. (1995). L' 'interesse straordinario' per il Mezzogiorno (1943-60). Meridiana, no. 24.

Dezalay Y. \& Garth B.G. (2011). Hegemonic battles, professional rivalries and the international division of labour in the market for the import and export of state-governing expertise. International Political Sociology, vol. 5, pp. 276-293.

Dyson K. \& Featherstone K. (1996). Italy and EMU as a Vincolo Esterno': Empowering the technocrats, transforming the state. South European Society and Politics, vol. 1, no. 2, pp. 272-299.

Eyal G. \& Bockman J. (2002). Eastern Europe as laboratory for economic knowledge: The transnational roots of neoliberalism. American Journal of Sociology, vol. 108, pp. 310-352.

Eyal G. \& Buchholz E. (2010). From the Sociology of intellectuals to the sociology of intervention. Annual Review of Sociology, vol. 36, pp. 117-137.

Ferrari-Bravo L. \& Serafini A. (1973), Stato e Sottosviluppo. Il caso del Mezzogiorno Italiano. Feltrinelli editore, Milano.

Fourcade M. (2006). The construction of global profession: The transnationalization of economics. American Journal of Sociology, vol. 112, no. 1 (July), pp. 145-194.

Foucault M. (2013). Le parole e le cose. Un'archeologia delle scienze umane, Bur, Milano.

Foucault M (2004). Nascita della biopolitica. Corso al Collége de France (1978-1979). Feltrinelli editore, Milano.

Foxley A. (1983). Experimentos neoliberals en América Latina. Colecciòn Estudios CIEPLAN, Santiago Chile

Fouskas V. (1998). Italy, Europe, the left: The transformation of Italian communism and the European Imperative. Ashgate, London.

Gallo E. (2009). Italy and Spain: Different patterns of state/society complexes in the contemporary era. Journal of Contemporary European Studies, vol. 17, no. 2, pp. 255-270.

Gemelli G. (2005). Un imprenditore scientifico e le sue reti internazionali: Luigi Einaudi e la fondazione Rockefeller. Le Carte e la Storia, vol. 1, pp. 189-202.

Gill S. (1998). European governance and new constitutionalism: Economic and monetary union and alternatives to disciplinary neoliberalism in Europe. New Political Economy, vol. 3, no. 1, pp. 5-26.

Graziano M. (2007). Italia senza Nazione? Geopolitica di una identità difficile. Donzelli editore, Roma.

Haas P. (1992). Introduction: Epistemic communities and international policy coordination. International Organization, no. 46.

Klein N. (2007). The shock doctrine: the rise of disaster capitalism. PM Press, New York.

Lama L. (1976). Intervista sul sindacato, edited by Massimo Riva. Laterza, Roma and Bari.

Lutz V. (1963). Italy: A study in economic development. Oxford University Press, Oxford.

Magliulo A. (1999). La Costituzione economica dell'Italia nella nuova Europa. Un' interpretazione storica. Miscellanea Studi e note di economia, vol. 3, p. 99.

Masini F. (2004). SMEmorie della lira. Gli economisti italiani e l'adesione al sistema monetario europeo. Franco Angeli, Milano.

Masini F. (2012). Luigi Einaudi and the making of the neoliberal project. History of Economic Thought and Policy, pp. 39-59.

Mattei C. E. (2017). Austerity and repressive politics: Italian economists in the early years of the fascist government. The European Journal of the History of Economic Thought, vol. 24, no. 5.

Miller P. \& Rose N. (1990). Governing economic life. Economic and Society Journal, vol. 19, no. 1. 
Mitchell T. (2002). Rule of experts: Egypt, technopolitics, modernity. University of California Press, Stanford.

Negri A. (2012) [1977]. La forma Stato: Per la critica dell'economia politica della Costituzione. Baldinig Castoldi Dalai editore, Milano.

Patriarca S (2012). A total science: statistics in liberal and fascist Italy. Journal of Modern Italian Studies, vol. 17 , no. 4.

Peluffo P. (2000). "Il cavallo non beve": Dibatti degli anni Sessanta su politica monetaria e programmazione economica. In Guido Carli, Scritti scelti, a cura di Paolo Peluffo Federico Carli. Laterza, Roma and Bari.

Persico A.A. (2014). Il codice Camaldoli. La DC e la ricerca della 'terza via' tra Stato e mercato (1943-1993). Guerini editore, Milano.

Quaglia L. (2005). Civil servants, economic ideas and economic policies: Lessons from Italy. governance. International Journal of Policy, Administration and Institutions, vol. 18, no. 4, pp. 545-566.

Radaelli C.M. (1999). The public policy of the European Union: Whither politics of expertise? Journal of European Public Policy, vol. 6, no. 5, pp. 757-774.

Renda F. (1980). Contadini e democrazia in Italia 1943-1947. Guida Editori, Napoli.

Righi A. (2011). Biopolitics and social change in Italy: From Gramsci to Pasolini to Negri. New York: Palgrave Macmillan.

Rosenstein-Rodan P. (1943). Problems of industrialization of Eastern and South-Eastern Europe. The Economic Journal, vol. 53, no. 210-211, pp. 202-211.

Rosenstein-Rodan P. (1944). The international development of economically backward areas. International Affairs (Royal Institute of International Affairs 1944), vol. 20, no. 2 (April), pp. 157-165.

Sanyal K. (2008). Rethinking capitalist development: Primitive accumulation, governmentality and post-colonial capitalism. Routledge, London.

Salento, A. (2014). The neo-liberal experiment in Italy: False promises and social disappointments. CRESC Working paper series. University of Manchester.

Scatamacchia R. (2005). Un laboratorio per la Ricostruzione: Il Servizio Studi della Banca d'Italia. In Politiche scientifiche e strategie di impresa: le culture olivettiane e i loro contesti, edited by G. Gemelli. Adriano Olivetti Foundation, Rome.

Sylos Labini P. (1972). Sindacati, inflazione e produttività. Laterza, Roma and Bari.

Tronti M. (2006) [1966]. Operai e capitale. Derive e Approdi, Roma.

Van Apeldoorn B. (2002). Transnational capitalism and the struggle over European integration. Routledge, London and New York.

Van der Pijl K. (2011). The wage of discipline: Rethinking international relations as vehicle of Western hegemony, spectrum. Journal of Global Studies, vol. 4, no. 1, pp. 5-26.

Wallerstein I. (2001). Unthinking social-sciences: The limits of nineteenth-century paradigms. Temple University Press, Philadelphia.

Wright O. (2002). Storming heaven: Class composition and struggle in Italian autonomist Marxism. Pluto Press, London. 